Л. Я. Посоленик, О. Я. Видойник, О. В. Авдєєв

ДВНЗ “Тернопільський державний медичний університет імені

I. Я. Горбачевського МОЗ України”

\title{
АКТУАЛЬНІ ПИТАННЯ ПІДГОТОВКИ ТА ОЦІНЮВАННЯ ЯКОСТІ ЗНАНЬ ЗДОБУВАЧІВ ВИЩОЇ ОСВІТИ В ГАЛУЗІ ЗНАНЬ “ОХОРОНА ЗДОРОВ’Я” ШЛЯХОМ СКЛАДАННЯ ТЕСТОВИХ ІСПИТІВ. НАПЕРЕДОДНІ ЗАПРОВАДЖЕННЯ ЄДКІ
}

\author{
L. Ya. Posolenyk, O. Ya. Vydoynyk, O. V. Avdeev \\ I. Horbachevsky Ternopil State Medical University \\ TOPICAL QUESTIONS FOR PREPARATION AND ASSESSMENT OF \\ KNOWLEDGE QUALITY OF HIGHER EDUCATION APPLICANTS \\ IN THE FIELD OF KNOWLEDGE “HEALTH PROTECTION” \\ BY COVERING TEST EXPERIENCES. ENVIRONMENTAL \\ IMPLEMENTATION OF THE ONE STATE QUALIFICATION EXAM
}

\begin{abstract}
Мета роботи - провести огляд літератури щодо застосування тестового контролю в оцінці рівня знань студентів-здобувачів вищої освіти у сфері медицини.

Основна частина. Медицина відноситься до такої сфери діяльності, де вимоги до рівня підготовки фахівців є вкрай високими, а контроль якості знань студентів, що здобувають освіту лікаря, часто є питанням життя або смерті. Завдяки імплементації інтерактивних методів підготовки та дистанційних онлайн-форм навчання створюються необхідні умови для безперервного підвищення якості, доступності й конкурентоспроможності національної освіти та науки на світовому ринку праці. Проведено аналіз сучасних навчально-методичних публікацій, присвячених удосконаленню підготовки до складання ліцензійних іспитів. За даними Центру тестування професійної компетентності фахівців з напрямів підготовки “Медицина” і “Фармація” при МОЗ України, середній результат складання субтесту з іноземної мови професійного спрямування ліцензійного іспиту Крок 1. 2018; спеціальності “Медицина”, “Стоматологія”, “Фармація” свідчить про середній, низький, а в окремих закладах вищої освіти дуже низький рівень володіння студентами громадянами України іноземною мовою професійного спрямування.

Висновки. Проведений огляд літератури вказує на те, що у вищих медичних навчальних закладах України існує достатньо новітніх інноваційних освітніх технологій, які дають широкі можливості вдосконалення знань, оптимізації підготовки та оцінки рівня знань студентів-здобувачів вищої освіти у медицині, і вони є ефективними. Водночас виявлено, що більша увага приділяється студентам старших курсів та лікарям-інтернам при підготовці до ліцензійних іспитів “Крок 2” і “Крок 3”. Удосконалення та більш широке впровадження онлайн-систем підготовки й оцінки рівня знань студентів до субтесту з іноземної мови професійного спрямування ліцензованого іспиту “Крок 1” сприятиме підвищенню рівня професійної підготовки, розвитку компетентностей студентів, необхідних для оволодіння майбутньою професією.
\end{abstract}

Ключові слова: тестування; Крок; студенти; лікарі-інтерни; онлайн-система навчання.

The aim of the work - to review the literature on the application of test control in assessing the level of knowledge of students seeking higher education in the field of medicine.

The main body. Medicine belongs to such a field of activity where the requirements for the level of training of specialists are extremely high, and the quality control of the knowledge of students receiving a doctor's education is often a matter of life or death. Thanks to the implementation of interactive training methods and online distance learning forms, the necessary conditions are created for the continuous improvement of the quality, accessibility and competitiveness of national education and science in the global labor market. The analysis of modern educational and methodical publications devoted to improving the preparation for the licensing exams was made. According to the Center for Testing Professional Competence of Specialists in the areas of preparation "Medicine" and "Pharmacy" at the Ministry of Health of Ukraine "the average result of the addition of the foreign language subtest in the professional direction of licensing exam Krok 1. 2018; specialties” Medicine “,” Dentistry “,” Pharmacy “ indicates a medium, low, and in some institutions of higher education is very low, the level of proficiency of students by citizens of Ukraine in a foreign language professional direction.

Conclusions. The review of the literature indicates that in higher medical educational institutions of Ukraine there are enough of the latest innovative educational technologies that provide ample opportunities to improve knowledge, optimize training and assess the level

(с) Л. Я. Посоленик, О. Я. Видойник, О. В. Авдєєв 
of knowledge of students seeking higher education in medicine, and they are effective. At the same time, it was found that more attention is paid to senior students and interns in preparing for the licensing examinations Krok 2 and Krok 3. Improving and wider introduction of online systems for training and assessing students' knowledge for the foreign language subtest in the professional direction of the licensed Krok 1 exam will help to improve the level of professional training and develop students' competencies necessary to master their future profession.

Key words: testing; Krok; students; interns; online learning system.

Вступ. Медицина відноситься до такої сфери діяльності, де вимоги до рівня підготовки фахівців $€$ вкрай високими, а контроль якості знань студентів, що здобувають освіту лікаря, часто $є$ питанням життя або смерті. У більшості країн створена потужна внутрішня система оцінки знань студентів на всіх етапах навчання, щоб гарантувати високий рівень підготовки медичних та фармацевтичних фахівців [1]. Сучасні тенденції розвитку медичної освіти вимагають формування у студента готовності використовувати отримані знання, уміння й навички для вирішення практичних завдань у процесі професійної діяльності [2]. Сьогоднішні студенти вміло користуються різними гаджетами, що надає можливість швидко знаходити потрібну інформацію. Завдяки імплементації інтерактивних методів навчання створюються необхідні умови для безперервного підвищення якості, доступності й конкурентоспроможності національної освіти та науки на світовому ринку праці [3].

Зміна освітніх стандартів потребує інновацій не тільки у навчальному процесі, але й в засобах контролю якості його проведення [2]. 28 березня 2018 року було прийнято Постанову КМУ № 334 "Про затвердження Порядку здійснення єдиного державного кваліфікаційного іспиту для здобувачів ступеня вищої освіти “Магістр” за спеціальностями галузі знань 22 “Охорона здоров'я”. У Постанові для кожної спеціальності галузі визначено тестові компоненти єдиного державного кваліфікаційного іспиту (ЄДКІ) [4]. За державною програмою з підготовки спеціалістів, ліцензійний іспит є найбільш показовим критерієм якості освітнього процесу у сфері медицини.

Мета роботи - провести огляд літератури щодо застосування тестового контролю в оцінці рівня знань студентів-здобувачів вищої освіти у сфері медицини.

Основна частина. А. К. Білий зі співавторами (2018) [1] проаналізували сучасний стан і проблеми самостійної та індивідуальної підготовки студентів до ліцензійного іспиту “Крок 1. Фармація” у залежності кількості тестування та їх результативності від дня тижня та часу доби. Дослідження показало зростання кількості тестувань у вівторок і середу та залежно від часу доби - у проміжку між 17:00 год та 00:00 год, причому пік завантаження онлайн-системи припадав на період 22:00 та 23:00. Також автори запропонували інноваційний підхід підготовки студентів до іспиту з використанням онлайн-системи, що дозволяє проводити дистанційне тестування у навчальному та контрольному режимах, онлайн-консультації для студентів, аналіз результатів тестування у вигляді детального аналізу стану завантаженості онлайн-системи, а також залежності результативності тестування від названих вище факторів. Одержані результати дозволили стверджувати про високу затребуваність студентами онлайн-форм навчання загалом, та такої підготовки до ліцензійних іспитів зокрема, виявити періоди найбільшої завантаженості онлайн-систем та ефективно планувати стратегію онлайн-підтримки студентів викладачами.

О. А. Подплєтня і співавтори (2018) [5] розглянули досвід застосування дистанційної форми навчання, яка працює на відкритій і найбільш популярній платформі - Moodle, для підвищення якості підготовки висококваліфікованих фахівців-провізорів у Дніпропетровській медичній академії з метою надання викладачам і студентам вільного доступу до системи, яка дає змогу ефективно обмінюватися навчальним контентом, взаємодіяти он-лайн та використовувати сучасні технології для втілення в життя принципу “навчання будь-коли та будьде”. Автори доводять ефективність використання дистанційної системи навчання як позааудиторної форми організації самостійної роботи студентів і як заключного етапу для самопідготовки до ліцензійного іспиту “Крок 1” та “Крок 2”. Також автори вказують на те, що інноваційні технології навчання сприяють розвитку пізнавальних і когнітивних здібностей студентів, а саме: вміння вирішувати поставлені завдання, займатися збором, аналізом і синтезом даних, витягувати 3 них інформацію, самостійно мислити, володіти комунікативними навичками. Сучасні технології розкривають нові можливості викладання, навчання й оцінки здобутих студентами знань, дозволяють здійснювати постійний моніторинг оволодіння професійними компетенціями, оцінювати якість виконання тес- 
тових завдань, коригувати та індивідуалізовувати процес навчання у короткі терміни.

Підтримали ідею впровадження дистанційної форми навчання та самопідготовки лікарів-інтернів, які складають іспит “ Крок-З. Стоматологія”, i у Львівському національному медичному університеті імені Данила Галицького. О. Є. Січкоріз зі співавторами (2018) [6] оцінили переваги та недоліки даної форми підготовки й контролю рівня знань лікарів-інтернів протягом очного та заочного навчання шляхом проведення претестувань з аналітичним розбором складних тестових завдань. Із висновків авторів стає відомо, що запровадження дистанційного навчання дозволило лікарям-інтернам проходити претестування в зручний для них час із обов'язковим контролем хронометражу часу та можливістю ознайомлення із власними помилками, у той же час викладачі мають можливість здійснювати контроль за підготовкою до “ Крок-3” дистанційно та забезпечувати безперервність підготовки до ліцензійного іспиту. Проте дистанційне навчання не може бути рекомендованим як самостійна форма підготовки лікарів-інтернів до “Крок-3. Стоматологія”, оскільки вимагає високого рівня самодисципліни, хоча як інтегрований курс дозволяє виявити і сформувати групу ризику на підставі аналізу даних середньої кількості пропущених претестувань та середнього відсотка успішності.

В. В. Корнякова та співавтори (2018) [7] вивчили ефективність й інформативність використання тестового контролю для оцінки рівня знань, умінь і навичок молодших медичних спеціалістів під час навчання. Шляхом узагальнення досвіду роботи педагогічного колективу з використання різних видів і способів застосування тестового контролю знань та вмінь на етапі післядипломної освіти молодших медичних спеціалістів науковці з’ясували, що тестування має суттєві переваги над іншими формами контролю, тобто охоплює контролем великий обсяг матеріалу; потребує невеликих часових ресурсів для проведення та перевірки; порівняно нескладне в організації, що дає змогу спростити саму процедуру контролю - від його підготовки та здійснення до перевірки й аналізу, а також вивільнити час для практичної роботи на занятті. Проведений аналіз показав, що поєднання перевірки засобами тестового контролю з іншими методами і прийомами сприяє розвитку професійних компетенцій, активізує мотивацію до знань, стимулює самопідготовку, що збільшує конкурентоспроможність молодших медичних спеціалістів.
3 метою вдосконалення знань та оптимізації підготовки лікарів-інтернів до складання ліцензійного іспиту “Крок 3” зі спеціальності “Стоматологія” у Тернопільському державному медичному університеті імені І. Я. Горбачевського проводяться ректорські контрольні роботи вже із 2017 року під контролем відповідальних викладачів кафедри стоматології післядипломної освіти та спеціально створеної комісії центру тестування університету. У статті Г. В. Стойкевич та співаторів (2018) [8] проаналізовано результати проведення тестових контролів лікарів-інтернів за 2016, 2017 і 2018 роки та показано, що чітка організація навчального процесу під час підготовки лікарів-інтернів і контроль якості складання проміжних іспитів та ректорських контрольних робіт дають можливість покращити клінічне мислення, поглибити теоретичі знання, i, як результат, привели до покращення складання ліцензійного іспиту “Крок 3. Стоматологія”.

У пошуках шляхів підвищення якісної успішності студентів 5 курсу напрямку підготовки “Стоматологія” та поліпшення результатів складання ліцензійного тестового іспиту “Крок-2” викладачами кафедри ортопедичної стоматології Дніпропетровської медичної академії було доведено, що поетапний розбір тестових завдань на кожному практичному занятті із варіантами відповідей, з аналізом відповідності дистракторів змісту завдання та алгоритму обгрунтування відповіді сприяв кращому запам’ятовуванню тестів, що підтверджувалось результатами поточного тестування і робить можливим індивідуалізувати навчальний процес та покращити підготовку студентів [9].

За даними Центру тестування професійної компетентності фахівців з напрямів підготовки “Медицина” і “Фармація” при МОЗ України”, середній результат складання субтесту з іноземної мови професійного спрямування ліцензійного іспиту Крок 1. 2018; спеціальності “Медицина”, “Стоматологія”, “Фармація” свідчить про середній, низький, а в окремих закладах вищої освіти дуже низький рівень володіння студентами громадянами України іноземною мовою професійного спрямування, що свідчить про неналежний рівень підготовки вітчизняних та англомовних іноземних студентів з дисциплін, які входять до іспиту “Крок 1” і використання “компромісного методу” до встановлення критерію “склав”, що визначило критерії успішного складання тесту з іноземної мови професійного спрямування на рівні 30,5 \% [4, 10]. 
На сьогодні велике значення надається оцінці рівня знань фахівців у багаторівневій системі здобуття вищої освіти за спеціальностями напрямку “Охорона здоров’я”, які здатні до самостійної роботи та здійснювати раціональний вибір у складних ситуаціях, тобто мислити критично. Тестовий контроль $є$ одним з елементів освітньої реформи, який здатний забезпечити одержання незалежної, об’єктивної інформації про рівень знань молодих спеціалістів. Іспит “Крок” вже більше десяти років $є$ складовою частиною атестації студентів та лікарів-інтернів медиків, стоматологів і фармацевтів, тому технологія його створення, проведення та підготовки до нього добре знайома як здобувачам, так і викладачам навчальних закладів вищої освіти.

Враховуючи досвід імплементації інноваційних педагогічних технологій, зокрема онлайн-форм навчання та підготовки студентів і лікарів-інтернів у вищих навчальних закладах України, активізується мотивація до знань, стимулюється самопідготовка фахівців, розвиваються професійні компетенції, що збільшує конкурентоспроможність молодих спеціалістів і дозволяє реалізувати принципово нові підходи до побудови систем контролю якості оволодіння знаннями вищої медичної освіти. Поширена інтеграція об’єктивних процедур систематичних семестрової та поточної атестацій студентів і ліка-

\section{Список літератури}

1. Білий А. К. Онлайн-підготовка студентів до ліцензійного іспиту “Крок 1. Фармація” з органічної хімії: поточний стан, перспективи впровадження / А. К. Білий, О. Ю. Воскобойнік, С. І. Коваленко // Медична освіта. 2018. - № 4. - С. 26-30.

2. Досвід організації комплексного практично-орієнтованого іспиту зі спеціальності “Стоматологія” за принципами OSCE / T. О. Перцева, I. С. Шпонька, О. О. Гудар’ян, О. О. Фастовець // Медична освіта. 2018. - № 2. - С. 82-85.

3. Зміна формату проведення лекційних занять для студентів-медиків нового покоління / О. Б. Яременко, Д. Л. Федьков, Д. В. Добрянський [та ін.] // Медична освіта. - 2018. - № 4. - С. 117-120.

4. Булах I. Є. Напередодні запровадження ЄДКІ. Крок 1. 2018; спеціальності “Медицина”, “Стоматологія”, “Фармація” / І. Є. Булах, Л. П. Войтенко, Т. С. Слухай // Медична освіта. - 2018. - № 4. - С. 6-18.

5. Подплєтня О. А. Інноваційні технології в професійній освіті: сучасні тенденції та практика впровадження / О. А. Подплєтня, Т. М. Потапова, В. Ю. Слєсарчук // Медична освіта. - 2018. - № 4. - С. 77-80.

6. Інтеграція дистанційної форми в навчальний процес на післядипломному етапі підготовки лікарів-інтернів рів-інтернів шляхом переходу переважно до письмового й комп’ютерного тестування дають якісне оцінювання знань і можливість аналізу результатів та адміністрування складання єдиного державного кваліфікаційного іспиту (ЄДКІ).

Висновки. Проведений огляд літератури вказує на те, що у вищих медичних навчальних закладах України існує достатньо новітніх інноваційних освітніх технологій, які дають широкі можливості вдосконалення знань, оптимізації підготовки та оцінки рівня знань студентів-здобувачів вищої освіти у медицині, і вони є ефективними. Водночас виявлено, що більша увага приділяється студентам старших курсів та лікарям-інтернам при підготовці до ліцензійних іспитів “Крок 2” і “Крок 3”. Аналізуючи сучасні тенденції розвитку освіти, вважаємо актуальною високу затребуваність студентами онлайн-форм навчання загалом та при підготовці до ліцензійних іспитів.

Удосконалення та більш широке впровадження онлайн-систем підготовки та оцінки рівня знань студентів до субтесту з іноземної мови професійного спрямування ліцензованого іспиту “Крок 1" сприятиме підвищенню рівня професійної підготовки, розвитку компетентностей студентів, необхідних для оволодіння майбутньою професією.

до складання ліцензійного іспиту “Крок-3. Стоматологія”: реалії та перспективи / О. Є. Січкоріз, Т. І. Пупін, Л. Ю. Мінько [та ін.] // Медична освіта. - 2018. - № 2. С. $125-130$.

7. Корнякова В. В. Оцінювання якості знань молодших медичних спеціалістів засобами тестового контролю / В. В. Корнякова, О. Р. Боярчук, О. М. Мочульська // Медична освіта. - 2018. - № 4. - С. 136-140.

8. Стойкевич Г. В. Шляхи оптимізації підготовки лікарів-інтернів до ліцензійного інтегрованого іспиту “Крок 3” / Г. В. Стойкевич, О. І. Лебідь, К. М. Дуда // Медична освіта. - 2018. - № 4. - С. 182-184.

9. Методичні аспекти покращення підготовки студентів-випускників з ортопедичної стоматології до практично-орієнтованого та тестового ліцензійного іспитів / I. В. Машейко, П. Г. Герасимчук, Р. Ю. Матвєєнко [та ін.] // Медична освіта. - 2018. - № 1. - С. 35-38.

10. Булах I. Є. Аналіз результатів складання студентами громадянами україни субтесту з іноземної мови професійного спрямування ліцензійного іспиту “Крок 1. Стоматологія” 20.02.2018 року / І. Є. Булах, Л. П. Войтенко, М. Р. Мруга // Медична освіта. - 2018. - № 2. - С. 6-13. 


\section{References}

1. Bilyi, A.K., Voskoboinik, O.Yu., \& Kovalenko, S.I. (2018). Onlain-pidhotovka studentiv do litsenziinoho ispytu “Krok 1. farmatsiia” z orhanichnoi khimii: potochnyi stan, perspektyvy vprovadzhennia [Online training of students for the license test "Step 1. Pharmacy" on organic chemistry: current status, prospects of implementation]. Medychna osvita - Medical Education, 4, 26-30 [in Ukrainian].

2. Pertseva, T.O., Shponka, I.S., Hudarian, O.O., \& Fastovets, O.O. (2018). Dosvid orhanizatsii kompleksnoho praktychno-oriientovanoho ispytu zi spetsialnosti "Stomatolohiia” za pryntsypamy OSCE [Experience of organizing a complex practical-oriented examination on the specialty of Dentistry according to OSCE principles]. Medychna osvita - Medical Education, 2, 82-85 [in Ukrainian].

3. Yaremenko, O.B., Fedkov, D.L., \& Dobrianskyi, D.V. (2018). Zmina formatu provedennia lektsiinykh zaniat dlia studentiv-medykiv novoho pokolinnia [Changing the format of lectures for the new generation of medical students]. Medychna osvita - Medical Education, 4, 117-120 [in Ukrainian].

4. Bulakh, I.Ye., Voitenko, L.P., \& Slukhai, T.S. (2018). Naperedodni zaprovadzhennia YEDKI. Krok 1. 2018; spetsialnosti "Medytsyna”, "Stomatolohiia”, "Farmatsiia” [On the eve of the introduction of the EDCI. Krok 1. 2018; specialty of Medicine, Stomatology, Pharmacy]. Medychna osvita Medical Education, 4, 6-18 [in Ukrainian].

5. Podplyetnia, O.A., Potapova, T.M., \& Sliesarchuk, V.Yu. (2018). Innovatsiini tekhnolohii v profesiinii osviti: suchasni tendentsii ta praktyka vprovadzhennia [Innovative technologies in vocational education: current trends and implementation practice]. Medychna osvita - Medical Education, 4, 77-78 [in Ukrainian].

6. Sichkoriz, O.Ye., Pupin, T.I., \& Minko, L.Yu. (2018). Intehratsiia dystantsiinoi formy $\mathrm{v}$ navchalnyi protses na pisliadyplomnomu etapi pidhotovky likariv-interniv doskladannia litsenziinoho ispytu "Krok-3. stomatolohiia": realii ta perspektyvy [Integration of the distance form in the educational process at the graduation stage of the preparation of interns to the completion of the license exam "Krok-3. Dentistry": realities and perspectives]. Medychna osvita Medical Education, 2, 125-130 [in Ukrainian].

7. Korniakova, V.V., Boiarchuk, O.R., \& Mochulska, O.M. (2018). Otsiniuvannia yakosti znan molodshykh medychnykh spetsialistiv zasobamy testovoho kontroliu [Evaluation of the quality of knowledge of junior medical specialists by means of test control]. Medychna osvita - Medical Education, 4, 136-140 [in Ukrainian].

8. Stoikevych, H.V., Lebid, O.I., \& Duda, K.M. (2018). Shliakhy optymizatsii pidhotovky likariv-interniv do litsenziinoho intehrovanoho ispytu "Krok 3” [Ways of optimizing the training of interns to the licensed integrated exam "Krok 3”]. Medychna osvita - Medical Education, 4, 182-184 [in Ukrainian].

9. Masheiko, I.V., Herasymchuk, P.H., \& Matvieienko, R.Yu. (2018). Metodychni aspekty pokrashchennia pidhotovky studentiv-vypusknykiv z ortopedychnoi stomatolohii do praktychno-oriientovanoho ta testovoho litsenziinoho ispytiv [Methodological aspects of improving the training of graduate students from orthopedic dentistry to practical-oriented and test licensed exams]. Medychna osvita - Medical Education, 1, 35-38 [in Ukrainian].

10. Bulakh, I.Ye., Voitenko, L.P., \& Mruha, M.R. (2018). Analiz rezultativ skladannia studentamy hromadianamy Ukrainy subtestu z inozemnoi movy profesiinoho spriamuvannia litsenziinoho ispytu "Krok 1. Stomatolohiia" 20.02.2018 roku [Analysis of the results of the students' compilation of Ukrainian subtitles in a foreign language for the professional direction of the licensed exam Krok 1. Dentistry]. Medychna osvita - Medical Education, 2, 6-13 [in Ukrainian]. 